\title{
Investigations on DNA protective and antioxidant potential of chloroform and ethyl acetate fractions of Koelreuteria paniculata Laxm.
}

\author{
Manish Kumar ${ }^{1}$, Subodh Kumar ${ }^{2}$ and Satwinderjeet Kaur ${ }^{1 *}$ \\ ${ }^{1}$ Department of Botanical and Environmental Sciences, Guru Nanak Dev University, Amritsar-143005, Punjab, India. \\ ${ }^{2}$ Department of Chemistry, Guru Nanak Dev University, Amritsar-143005, Punjab, India.
}

Accepted 17 March, 2011

\begin{abstract}
Reactive oxygen (ROS) species have been known as a contributory factor in the etiology of cancer and various neurodegenerative diseases. ROS are produced as a result of normal metabolic processes occurring in the human body. Therapy using free radical scavengers have the potential to prevent, delay many disorders. The crude extracts and natural pure compounds from plants are reported to have antioxidant activity. Keeping this in mind, the chloroform fraction (KCF) and ethyl acetate fraction (KEA fraction) isolated from leaves of Koelreuteria paniculata (Sapindaceae) was investigated for its genoprotective potential against the DNA damage induced by Fenton's reagent in pUC18 plasmid DNA. Further, the fractions were examined for their superoxide anion radical scavenging, 2, 2- Diphenyl-1picrylhydrazyl (DPPH) radical scavenging, ABTS radical scavenging and reducing power potential. The fractions significantly protected the DNA damage induced by the hydroxyl radicals generated by Fenton's reagent. The KCF and KEA fractions scavenged the superoxide anions by $19.59 \%\left(E_{50}=N . D\right)$ and $67.12 \%\left(E_{50} 167.59 \mu \mathrm{g} / \mathrm{ml}\right)$ respectively, DPPH radicals by $79.96 \%\left(E_{50} 121.98 \mu \mathrm{g} / \mathrm{ml}\right)$ and $86.04 \%$ $\left(E_{50} 105 \mu \mathrm{g} / \mathrm{ml}\right)$ respectively; $A B T S$ cation radicals by $87.63 \%\left(E_{50} 75.48\right)$ and $94.3 \%\left(E_{50} 62.12\right)$ respectively and showed reducing potential of $95.27 \%\left(E_{50} 60.94 \mu \mathrm{g} / \mathrm{ml}\right)$ and $80.03 \%\left(E_{50} 72.70 \mu \mathrm{g} / \mathrm{ml}\right)$ respectively.
\end{abstract}

Key words: Reactive oxygen species, Fenton's reagent, genoprotective potential, DNA damage.

\section{INTRODUCTION}

Antioxidants play a vital role to protect human body against oxidative damage arising from free radicals or reactive oxygen species (Lollinger, 1981). The reactive oxygen species (ROS) have been known as a causative factor in the etiology of cancer and several neurodegenerative diseases e.g. Alzheimer's disease, Parkinson's disease, Down's syndrome, inflammation, viral infection and various other digestive disorders such as ulcer and gastrointestinal disorder (Reppeto and Llesuy, 2002; Surh and Ferguson, 2003). Many mutagens and carcinogens may act through the generation of reactive oxygen species (Zahin et al.,

${ }^{*}$ Corresponding author. E-mail: sjkaur2011@gmail.com
2010). ROS are produced as a result of normal metabolic processes occurring in the human body including respiratory chain reaction in mitochondria, liver mixed function oxidases, through xanthine-oxidase activity, atmospheric pollutants, drugs and various xenobiotics (Atawodi, 2005). Oxidative damage is regarded as endogenous damage leading to the aging process. Several organisms possess antioxidant defense system in their bodies but there is decline in these antioxidant defenses with age. Superoxides are converted to hydrogen peroxides by superoxide dismutases (SOD) and hydrogen peroxides are degraded by catalases. Hydrogen peroxide $\left(\mathrm{H}_{2} \mathrm{O}_{2}\right)$ is converted into hydroxyl radicals by Fenton's reaction and Haber-Weiss reactions which may result in severe cellular damage (Halliwell and Gutteridge, 1998). Free radical scavengers have the 


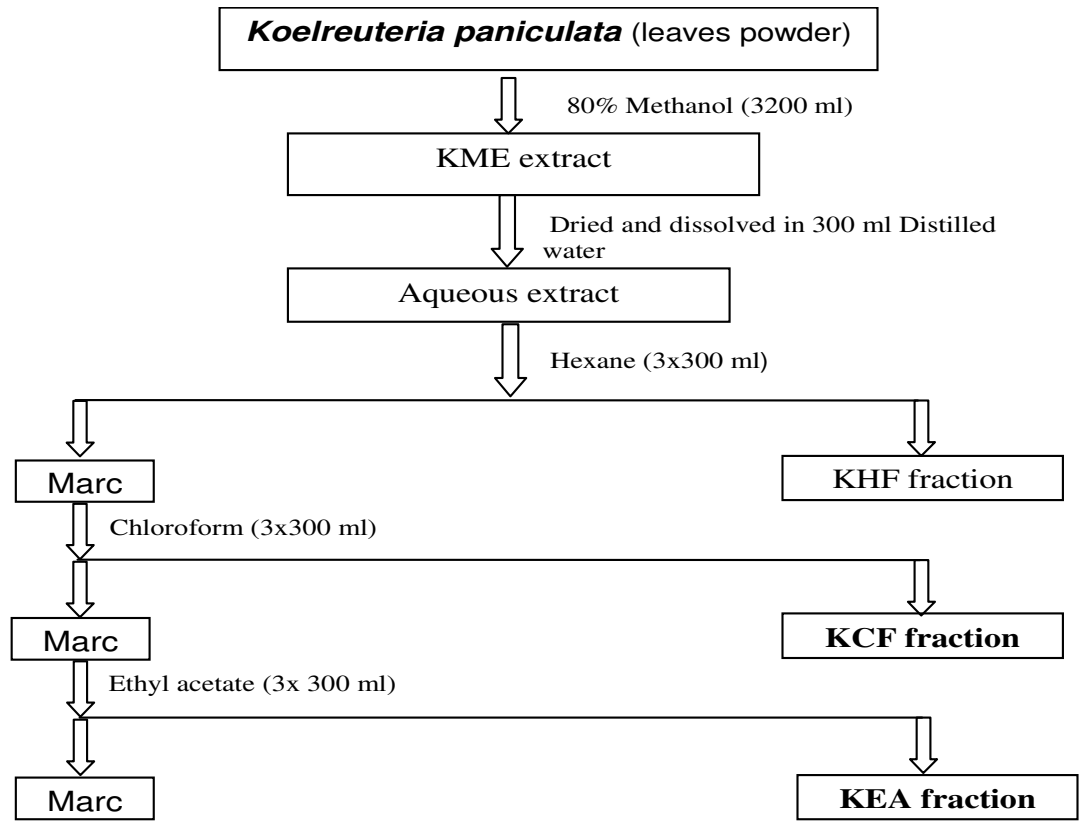

Flow chart 1. Extraction procedure for the preparation of KCF and KEA fractions of K. paniculata.

ability to prevent many disorders (Delanty and Ditcher, 2000). The antioxidant potential of phenolic compounds is the result of their redox properties, which permits them to act as reducing agents, hydrogen donors, singlet oxygen quenchers and metal chelators (CanadanovicBrunet et al., 2005; Pietta, 2000; Marimuthu et al., 2008). The large use of plant extracts in food, cosmetics and pharmaceutical industries suggests that the study of medicinal plants is necessary (Nostro et al., 2000; Canadanovic-Brunet et al., 2005). The flavonoids and phenolics have large distribution in nature and have received great interest because of their antioxidant, antimutagenic and antitumour activities (Li et al., 2009).

Koelreuteria paniculata Laxm. (Family Sapindaceae) is commonly known as 'golden rain tree'. The flowers of this plant are used to procure yellow dye and are used in various traditional medicines. Keeping in mind, the medicinal use of the plant in traditional medicine, it is planned to assess the DNA protective and antioxidant potential of chloroform (KCF fraction) and ethyl acetate (KEA fraction) fractions from leaves of $K$. paniculata Laxm.

\section{MATERIALS AND METHODS}

\section{Chemicals}

2, 2- Diphenyl-1-picrylhydrazyl (DPPH), Ferric chloride, nicotinamide adenine dinucleotide (NADH), phenazine methosulphate, nitrobluetetrazolium, 2,2-azinobis (3ethylbenzothiazoline-6-sulfonate) (ABTS) and BHT were obtained from HiMedia Pvt. Limited. Mumbai, India. Gallic acid, Ascorbic acid and Rutin were obtained from Sigma (St. Louis, MO, USA). pUC18 plasmid DNA was purchased from Genei Pvt. Ltd., Banglore, India. All other reagents were of analytical grade (AR).

\section{Plant material}

\section{Collection of plant material}

The leaves of the plant were collected in month of November, 2009 from Botanical garden of Guru Nanak Dev University, Amritsar, Punjab. The specimen was identified by the Herbarium of Department of Botanical and Environmental Sciences and voucher specimen No. 0409/HRB was deposited in herbarium of in the same Department.

\section{Extraction and Isolation}

The leaves were washed with running tap water to remove dust impurities and finally air dried in shade. The dried leaves were ground to fine powdered and extracted three times with $80 \%$ methanol and concentrated under reduced pressure using rotary vacuum evaporator to obtain KME extract. Then KME extract was made aqueous with distilled water and fractionated with different solvents viz. Hexane (KHF fraction), chloroform (KCF fraction) and ethyl acetate (KEA fraction) in increasing order of solvent polarity to obtain respective fractions (flow Chart 1 ).

\section{DNA protection assay}

DNA protection assay was performed using supercoiled pUC18 plasmid DNA (Lee et al., 2002) with slight modifications. Plasmid DNA was incubated with Fenton's reagent $\left(30 \mathrm{mM} \mathrm{H}_{2} \mathrm{O}_{2}, 50 \mathrm{mM}\right.$ ascorbic acid and $80 \mathrm{mM} \mathrm{FeCl}_{3}$ ) containing extract/fractions and the 
final volume of the mixture was raised up to $20 \mu \mathrm{l}$. The mixture was then incubated for $30 \mathrm{~min}$ at $37^{\circ} \mathrm{C}$ followed by the addition of loading dye and the electrophoresis was carried out in TAE buffer (40 mM Tris base, $16 \mathrm{mM}$ acetic acid 1mM EDTA, pH 8.0). DNA was analyzed followed by ethidium bromide staining. The gallic acid was used as positive control.

\section{Antioxidant assays}

\section{Superoxide anion radical scavenging assay}

The measurement of superoxide anion scavenging activity of different test samples was performed by the method described by Nishikimi et al. (1972) with slight modifications. About $1 \mathrm{ml}$ of nitroblue tetrazolium (NBT) solution (156 $\mu \mathrm{M}$ prepared in $100 \mathrm{mM}$ phosphate buffer, $\mathrm{pH} 7.4), 1 \mathrm{ml}$ of $\mathrm{NADH}$ solution $(468 \mu \mathrm{M}$ prepared in $100 \mathrm{mM}$ phosphate buffer $\mathrm{pH} 7.4$ ) and various concentration of test samples (100 to $500 \mu \mathrm{g} / \mathrm{ml}$ ) were mixed and the reaction started by adding $100 \mu \mathrm{l}$ of phenazine methosulphate (PMS) solution $(60 \mu \mathrm{M})$ prepared in phosphate buffer $(100 \mathrm{mM}, \mathrm{pH} 7.4)$. The reaction mixture was incubated at $25^{\circ} \mathrm{C}$ for $5 \mathrm{~min}$ and the absorbance at $560 \mathrm{~nm}$ was measured against the control samples. Rutin was used as the reference compound:

Radical scavenging activity $\left.\%=\left[A_{0}-A_{1} / A_{0}\right) \times 100\right]$

Where $A_{0}$ is the absorbance of control, $A_{1}$ is the absorbance of test sample.

\section{Reducing power assay}

Reducing potential of test sample was determined using the method of Oyaizu (1986). The different concentrations (20 to 200 $\mu \mathrm{g} / \mathrm{ml})$ of test samples were mixed with phosphate buffer $(2.5 \mathrm{ml}$, $0.2 \mathrm{M}, \mathrm{pH} 6.6)$ and potassium ferricyanide $\left[\mathrm{K}_{3} \mathrm{Fe}(\mathrm{CN})_{6}\right](2.5 \mathrm{ml}, 1 \%)$. The mixture was incubated at $50^{\circ} \mathrm{C}$ for $20 \mathrm{~min}$. Aliquots $(2.5 \mathrm{ml})$ of trichloroacetic acid (10\%) were added to the mixture, which was then centrifuged for $10 \mathrm{~min}$ at $1036 \mathrm{~g}$. The upper layer of solution $(2.5 \mathrm{ml})$ was mixed with distilled water $(2.5 \mathrm{ml})$ and $\mathrm{FeCl}_{3}(2.5 \mathrm{ml}$, $0.1 \%$ ) and the absorbance was measured at $700 \mathrm{~nm}$ in a spectrophotometer. Increased absorbance of the reaction mixture indicated increased reducing power.

$\%$ Reducing power $=[1-(1-\mathrm{As} / \mathrm{Ac}) \times 100]$

Where $A c=$ absorbance of standard at maximum concentration tested, As = absorbance of test sample.

\section{DPPH-radical scavenging assay}

The test samples were measured in terms of hydrogen-donating or radical-scavenging ability using the stable radical DPPH ${ }^{*}$ (Blois, 1958). Briefly, the reaction mixture contained $100 \mu \mathrm{l}$ of different fraction concentrations (20 to $200 \mu \mathrm{g} / \mathrm{ml})$ and $2 \mathrm{ml}$ of DPPH $(0.1$ $\mathrm{mM}$ in methanolic solution). The reaction mixture was then placed in the cuvette holder of the spectrophotometer (Systronic 2202 UV VIS spectrophotometer) against the blank, which did not contain test sample and read at $517 \mathrm{~nm}$. The L-ascorbic acid was used as the positive control. The percent DPPH decolorisation of the sample was calculated by:

Radical scavenging activity $\left.\%=\left[A_{0}-A_{1} / A_{0}\right) \times 100\right]$

where $A_{0}$ is the absorbance of control (without test sample), $A_{1}$ is the absorbance of reaction mixture (with test sample).

\section{ABTS cation radical scavenging assay}

$\mathrm{ABTS}^{+}$scavenging assay was carried out by the method given by Re et al. (1999). The $\mathrm{ABTS}^{+}$radical cation was pregenerated by mixing $7 \mathrm{mM}$ ABTS stock solution with $2.45 \mathrm{mM}$ potassium persulfate and incubating for 12 to $16 \mathrm{~h}$ in the dark at room temperature until the reaction was complete and the absorbance becomes stable. The absorbance of the $\mathrm{ABTS}^{+}$solution was equilibrated to $0.70( \pm 0.02)$ by diluting with ethanol at room temperature. $100 \mu \mathrm{l}$ of the test sample (40 to $200 \mu \mathrm{g} / \mathrm{ml}$ ) was added to diluted ABTS solution and absorbance reading was taken at 734 $\mathrm{nm}$ up to $5 \mathrm{~min}$ BHT was used as standard antioxidant:

Radical scavenging activity $\left.\%=\left[A_{0}-A_{1} / A_{0}\right) \times 100\right]$

where $A_{0}$ is the absorbance of control (without test sample), $A_{1}$ is the absorbance of reaction mixture (with test sample).

\section{Phytochemical analysis}

\section{Determination of total phenolic content (TPC)}

The TPC of the test sample was determined using Folin-Ciocalteu (FC) method (Yu et al., 2002) employing gallic acid as standard. To the $100 \mu \mathrm{l}$ of concentration $100 \mu \mathrm{g} / \mathrm{ml}$ of test samples was added $900 \mu \mathrm{l}$ of double distilled water. To this $500 \mu \mathrm{l}$ of FC reagent was added. This was followed by the addition of $1.5 \mathrm{ml}$ of $20 \%$ sodium carbonate. The mixture was shaken thoroughly and allowed to stand for $2 \mathrm{~h}$. The volume of mixture was made up to $10 \mathrm{ml}$ with distilled water and allowed to stand for $2 \mathrm{~h}$. Finally absorbance was taken at $765 \mathrm{~nm}$. The phenolic content was calculated as $\mathrm{mg}$ $\mathrm{GAE} / \mathrm{g}$ dry wt. of sample on the basis of standard curve of gallic acid.

\section{Determination of total flavonoid content (TFC)}

The method given by Kim et al. (2003) was used for determination of total flavonoid content (TFC) employing rutin as a standard. Total flavonoid content of the extract/fraction was determined using colorimetric method. To $1 \mathrm{ml}$ of $100 \mu \mathrm{g} / \mathrm{ml}$ concentration of test samples, $4 \mathrm{ml}$ of double distilled water was added followed by addition of $300 \mu \mathrm{l}$ of $\mathrm{NaNO}_{2}$ and $300 \mu \mathrm{l}$ of $\mathrm{AlCl}_{3}$ then this mixture was incubated for $5 \mathrm{~min}$. To this $2 \mathrm{ml}$ of $\mathrm{NaOH}$ was added and final volume was raised to $10 \mathrm{ml}$. Finally absorbance was taken at 510 $\mathrm{nm}$. TFC was then expressed as rutin equivalents (RE) in $\mathrm{mg} / \mathrm{g}$ of dry sample.

\section{Statistical analysis}

All experiments were repeated at least three times. Results are expressed as mean \pm S.E. $I_{50}$ values were calculated by regression analysis.

\section{RESULTS}

The DNA protective potential of KCF and KEA fractions of $K$. paniculata was studied in pUC18 DNA protection assay. The effect of the fractions was compared with standard antioxidant compound gallic acid. The concentration of fractions used was $50 \mu \mathrm{g} / \mathrm{ml}$. Both the fractions protected the DNA from hydroxyl radicals 


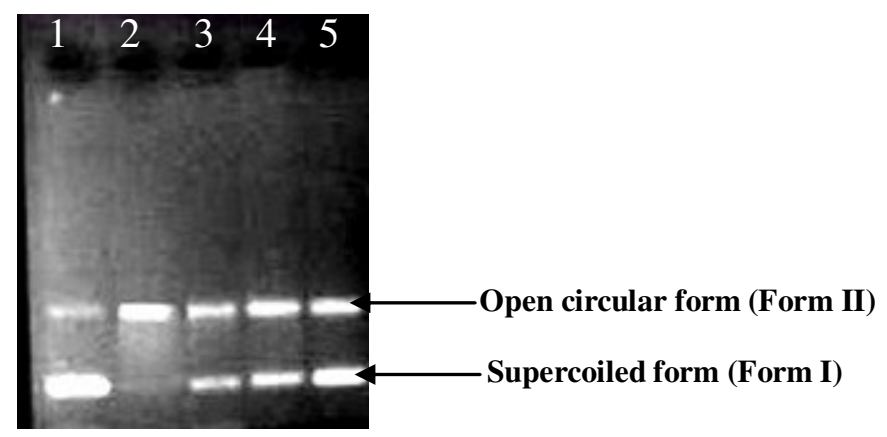

Figure 1. Effect of Koelreuteria paniculata leaf fractions on the protection of supercoiled pUC18 DNA against hydroxyl radical generated by the $\mathrm{H}_{2} \mathrm{O}_{2}$. Lane 1: pUC18 DNA Lane 2: pUC18 DNA + Fenton's reagent (DNA damage control), Lane 3: pUC18 DNA + Fenton's reagent + Gallic acid (Standard) $(50 \mu \mathrm{g} / \mathrm{ml})$, Lane 4: pUC18 DNA + Fenton's reagent + KCF fraction $(50 \mu \mathrm{g} / \mathrm{ml})$, Lane 5: pUC18 DNA + Fenton's reagent + KEA fraction (50 $\mu \mathrm{g} / \mathrm{ml})$.

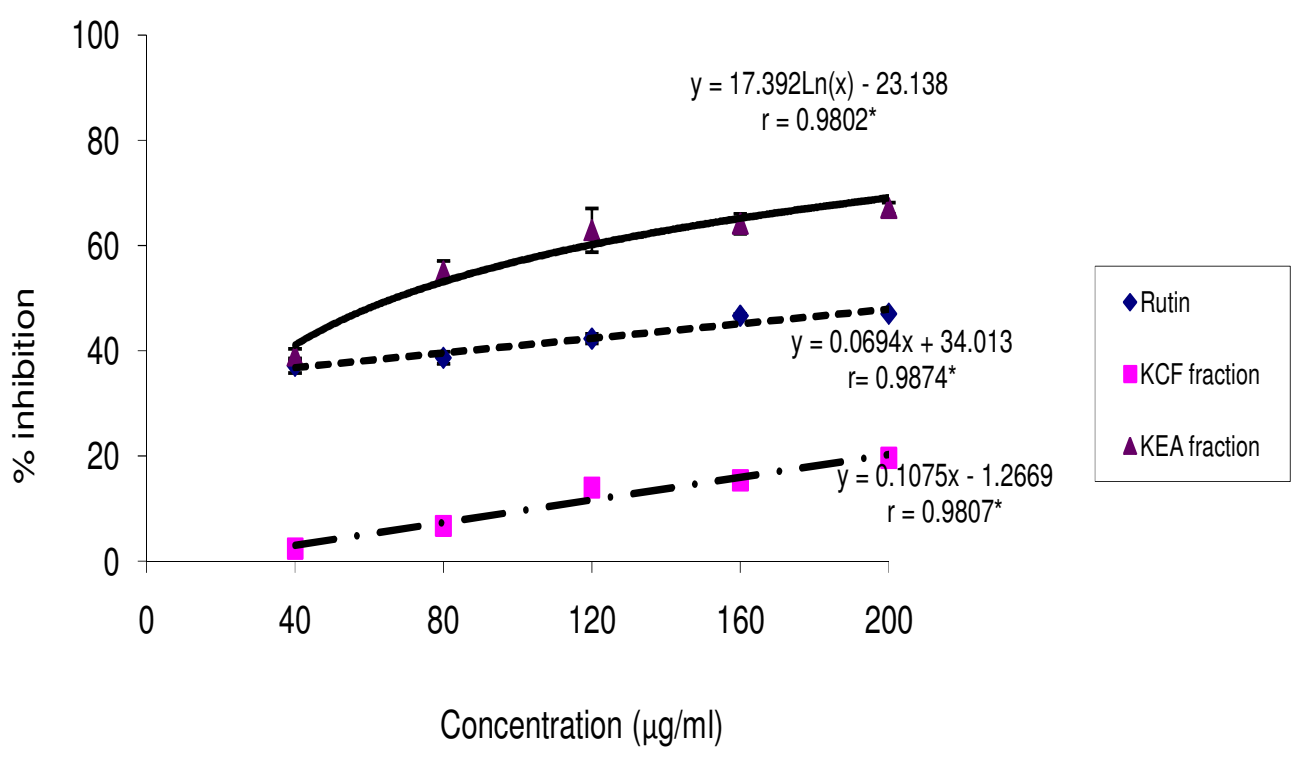

Figure 2. Scavenging effects of KCF and KEA fractions of $K$. paniculata leaves and standard rutin on superoxide anion radicals, $\mathrm{p} \leq 0.05^{*}$.

generated by Fenton's reaction (Figure 1).

Superoxide radical scavenging activity of different extract/fractions was determined using non-enzymatic PMS-NADH system. The decrease in absorbance at 560 $\mathrm{nm}$ in the presence of antioxidants indicates the consumption of superoxide radical in the reaction mixture. Figure 2 shows the superoxide radical scavenging activity of KCF and KEA fractions of $K$. paniculata. KEA fraction showed very good potential for scavenging superoxide radical $\left(\mathrm{IC}_{50} 167.59 \mu \mathrm{g} / \mathrm{ml}\right)$ while KCF demonstrated only $19.59 \%$ of inhibition.

The reducing ability of a compound commonly depends on the occurrence of reductants which have the ability to break the free radical chain by donating a hydrogen atom (Gordon, 1990). The presence of reductants in KCF and KEA fraction causes the reduction of the $\mathrm{Fe}^{3+}$ ferricyanide complex to the ferrous form. Therefore, the $\mathrm{Fe}^{2+}$ can be monitored by measuring the formation of Perl's Prussian blue at $700 \mathrm{~nm}$. The reductive potential of the KCF and KEA fractions in comparison to ascorbic acid showed good scavenging ability with $\mathrm{IC}_{50}$ value of 60.94 and $72.70 \mu \mathrm{g} / \mathrm{ml}$ respectively (Figure 3 ). The KCF and KEA fractions exhibited $I_{50}$ value even less than that of standard ascorbic acid $\left(\mathrm{IC}_{50}\right.$ value $\left.=103.85 \mu \mathrm{g} / \mathrm{ml}\right)$ showing that these two fractions have comparatively good reducing ability in comparison to the standard. 


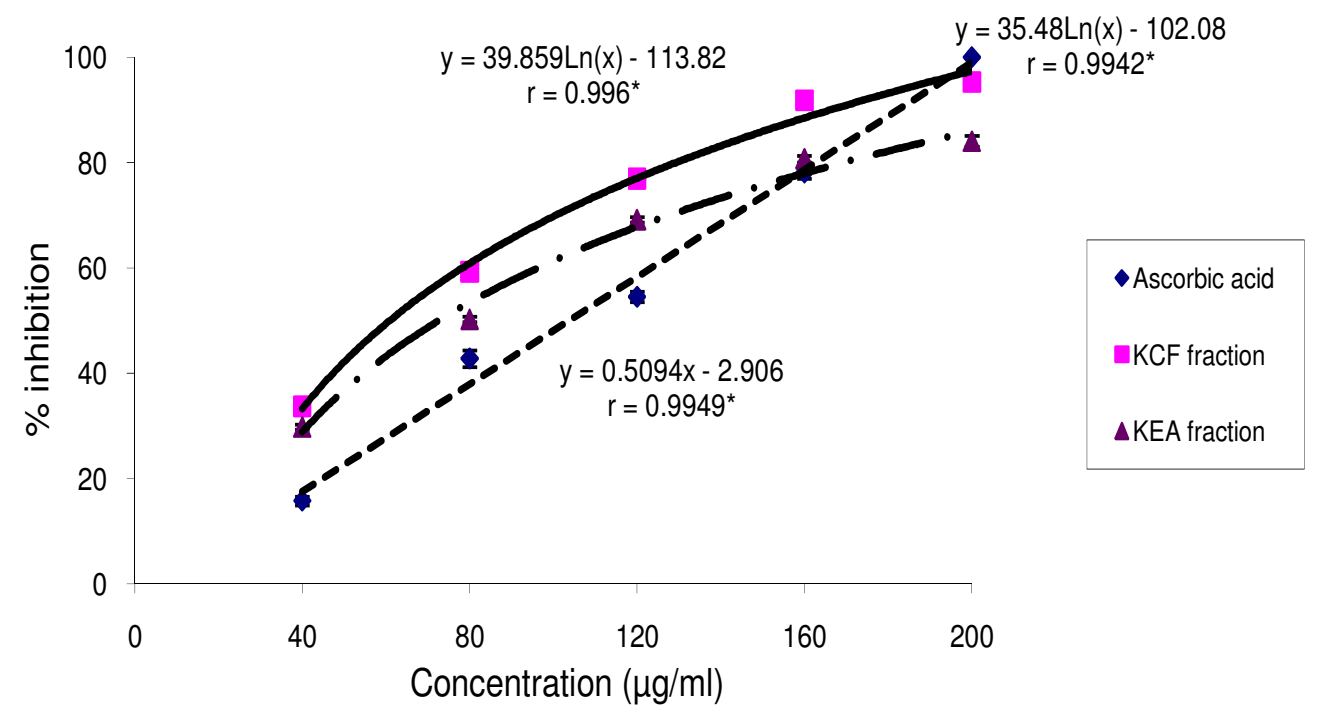

Figure 3. Reducing potential of KCF and KEA fractions of $K$. paniculata leaves in comparision to standard asorbic acid, $\mathrm{p} \leq 0.05^{\star}$.

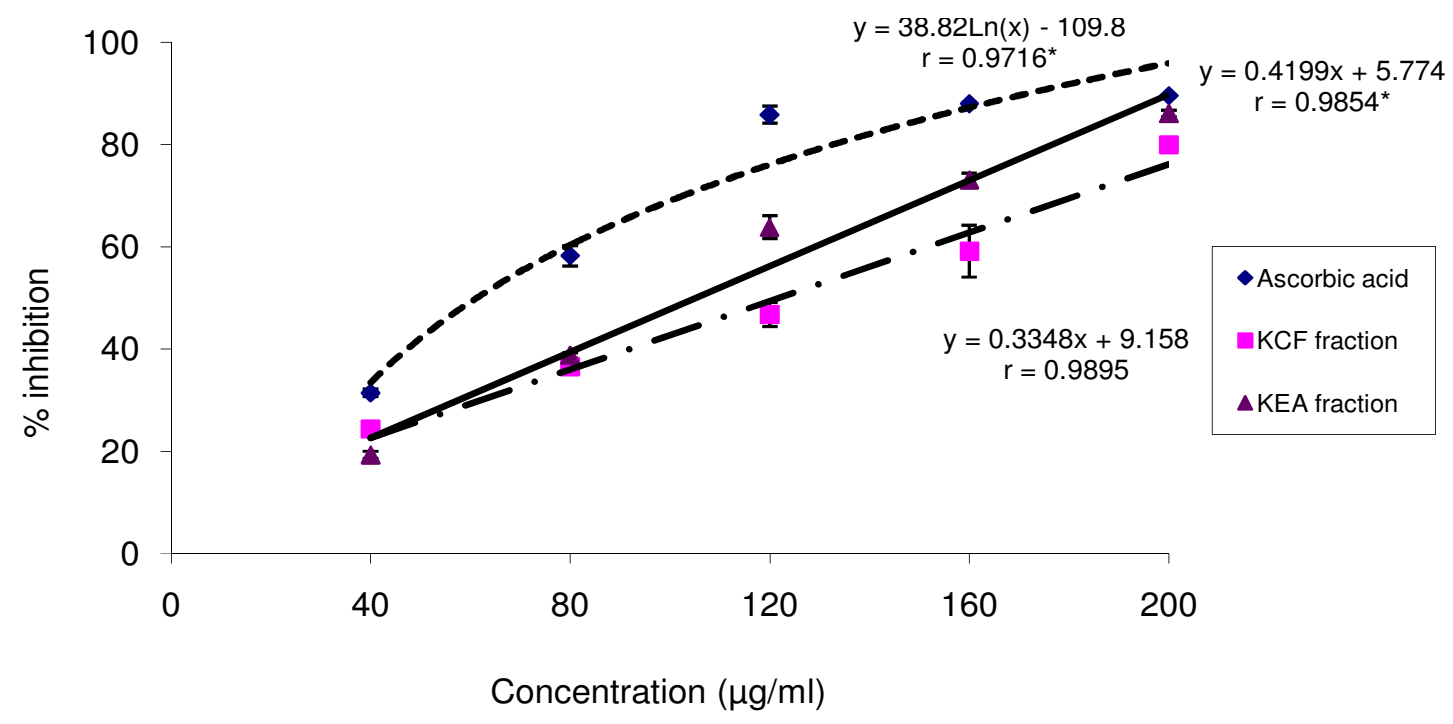

Figure 4. Scavenging effects of KCF and KEA fractions of $K$. paniculata leaves and standard ascorbic acid on DPPH radicals, $\mathrm{p} \leq 0.05^{\star}$.

The use of DPPH free radical is common method to evaluate the antioxidant potential (Stupans et al., 2002). The KCF and KEA fractions of $K$. paniculata were checked at different concentrations from 20 to $200 \mu \mathrm{g} / \mathrm{ml}$ and activities were compared with ascorbic acid as standard. The KEA fraction showed more proton donating ability $\left(\mathrm{IC}_{50}\right.$ value $\left.=105 \mu \mathrm{g} / \mathrm{ml}\right)$ as compared to the KCF fraction $\left(\mathrm{IC}_{50}\right.$ value $\left.=121.98 \mu \mathrm{g} / \mathrm{ml}\right)$. The standard ascorbic acid showed $\mathrm{IC}_{50}$ value of $55.88 \mu \mathrm{g} / \mathrm{ml}$ (Figure 4).

In ABTS assay, the KCF fraction exhibited antioxidant activity of $87.63 \%\left(\mathrm{IC}_{50}\right.$ of $\left.75.48 \mu \mathrm{g} / \mathrm{ml}\right)$ while KEA fraction showed $94.3 \%$ of inhibition ( $\mathrm{IC}_{50}$ value $\left.62.12 \mu \mathrm{g} / \mathrm{ml}\right)$. The standard compound $\mathrm{BHT}$ showed $51.6 \%$ inhibition $\left(\mathrm{IC}_{50}\right.$ value $197.55 \mu \mathrm{g} / \mathrm{ml}$ ) (Figure 5). The phytochemical analysis of the fractions revealed that KCF and KEA fractions showed phenolic content of 372.5 and 277.5 $\mathrm{mg} / \mathrm{g}$ of gallic acid equivalents and flavonoid content 260 and $253.1 \mathrm{mg} / \mathrm{g}$ of rutin equivalents, respectively.

\section{DISCUSSION}

Free radicals can cause damage to DNA as reported by 


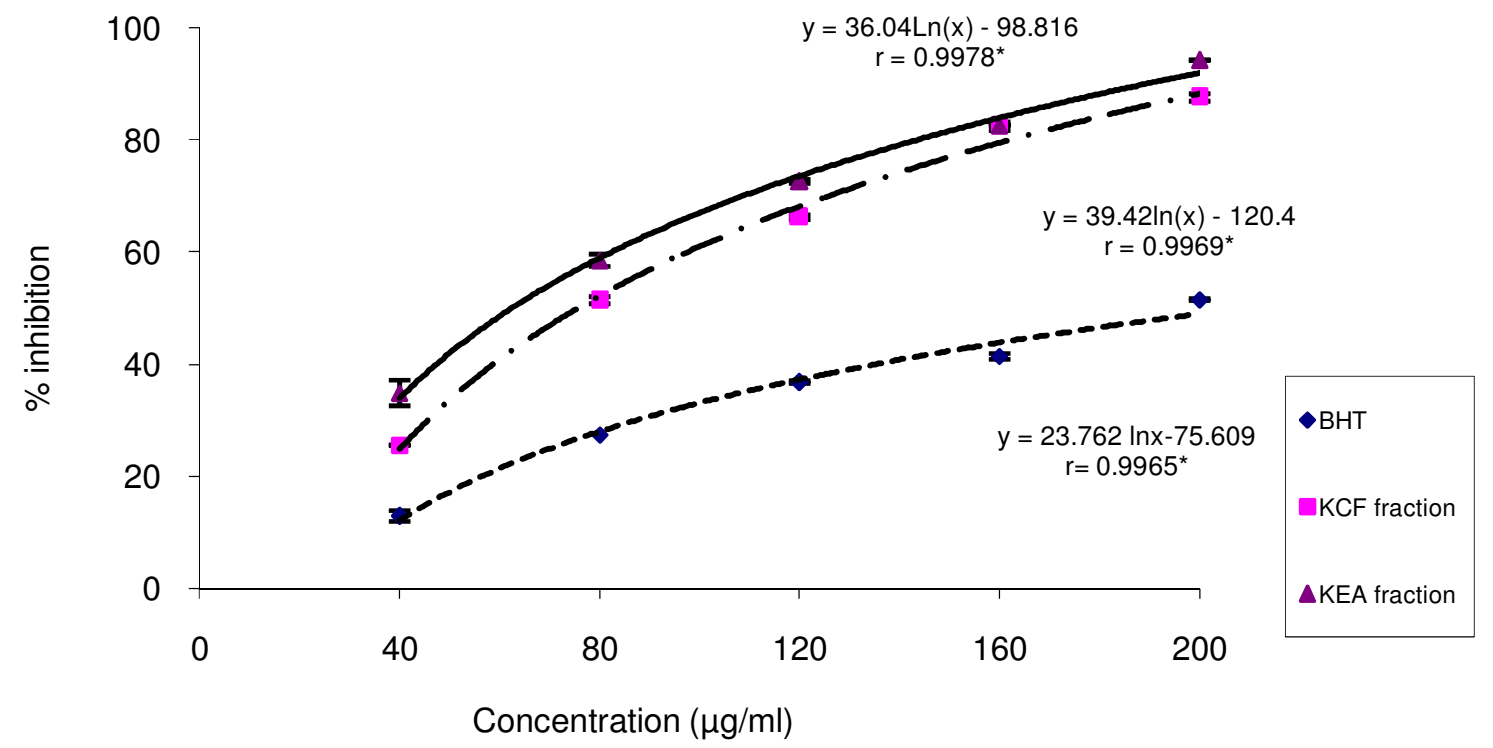

Figure 5. Scavenging effects of KCF and KEA fractions of $K$. paniculata leaves and standard BHT on ABTS cation radicals, $p \leq 0.05^{\star}$.

many studies (Kumar et al., 1999; Lloyd and Philips, 1999). Hydroxyl radical generated by Fenton's reagent attacks supercoiled pUC18 plasmid DNA and causes single stranded scission (resulting in nicked circular form II) or double stranded breaks (resulting in linear form III). In the present study, the addition of KCF and KEA fractions along with Fenton's reagent provide protection to plasmid DNA, resulting in retention of the native form. The effect of the fractions was compared with standard antioxidant gallic acid. Suganthy et al. (2009) reported that methanolic extracts of $R$. mucronata were effective in shielding plasmid DNA against the damage induced by hydroxyl radicals in a Fenton's reaction mixture.

Superoxide anion is a weak oxidant, it gives rise to generation of powerful and dangerous hydroxyl radicals as well as singlet oxygen, both of which contribute to oxidative stress (Meyer and Isaken, 1995). Various biological reactions generate superoxide anions which are highly toxic species. In the PMS/NADH-NBT system, the superoxide anion derived from dissolved oxygen from PMS/NADH coupling reaction reduces yellow NBT (nitrobluetetrazolium) to blue formazan. The decrease of absorbance at $560 \mathrm{~nm}$ with antioxidants, indicates the consumption of superoxide anion in the reaction mixture. Antioxidants are able to inhibit the blue NBT formation (Cos et al., 1998). KEA fraction was found to be more active scavenger of superoxide radicals than KCF fraction. KEA fraction even showed more scavenging potential than standard rutin.

The reducing ability of the plant extract may serve as a significant indicator of its potential antioxidant activity (Meir et al., 1995). A higher absorbance indicates a higher ferric reducing power of plant extracts. Earlier many studies have reported that the electron donation power of bioactive compounds is related with antioxidant activity (Siddhuraju et al., 2002). Figure 2 shows the reducing powder of both fractions compared with ascorbic acid. KCF fraction demonstrated higher reducing power compared to the KEA fraction. Reducing powers of KCF fraction was $95.27 \%$, whereas that of KEA extract was $84.03 \%$ at $200 \mu \mathrm{g} / \mathrm{ml}$ in comparison to ascorbic acid. With regards to reducing capacity, higher reducing powers might be attributed to higher amounts of total phenolic and flavonoid, and the reducing power of a compound may reflect its antioxidant potential (Lee et al., 2007). Different studies have indicated that the reducing properties are generally associated with the presence of reductones, which have been shown to exert antioxidant action by breaking the free radical chain by donating a hydrogen atom (Shon et al., 2003). Hence, the reducing ability of both fractions may be due to its phenolic and flavonoid compounds.

The DPPH antioxidant assay is based on the ability of $\mathrm{DPPH}$, a stable free radical to decolorize in the presence of antioxidants. DPPH assay is simple, rapid, sensitive and reproducible (Ozcelik et al., 2003). The DPPH radical contains an odd electron, which is responsible for the absorbance at $517 \mathrm{~nm}$ and also for visible deep purple color. When DPPH accepts an electron from the test compound, the DPPH is decolorized which can be quantitatively measured from the changes in absorbance. Comparison of the antioxidant activity of the KCF and KEA fractions with ascorbic acid demonstrated high scavenging activity of KEA fraction than KCF fraction, but both the fractions showed less scavenging ability than standard ascorbic acid (Figure 1). 
ABTS $^{\circ+}$ assay is an excellent tool to find out the antioxidant activity of hydrogen donating and chain breaking antioxidants. Pietta et al. (1998) evaluated the total antioxidant activity of medicinal plants and reported that the phenolic compounds play an important role in scavenging of $\mathrm{ABTS}^{++}$. $\mathrm{ABTS}^{++}$has characteristic absorbance maxima at $734 \mathrm{~nm}$ which decreases with the scavenging of the proton radicals (Yoshida et al., 1999). In our studies, both KCF and KEA fractions showed scavenging activity more than standard BHT. The scavenging potential of these fractions may be a contribution of their phenolic and flavonoid compounds.

\section{ACKNOWLEDGEMENTS}

The authors are thankful for financial assistance provided by University Grants Commission (UGC), New Delhi.

\section{REFERENCES}

Atawodi S (2005). Antioxidant potential of African medicinal plants. Afr. J. Biotechnol., 4: 128-133.

Blois MS (1958). Antioxidant determinations by the use of a stable free radical. Nature, 181: 1199-1200.

Canadanovic-Brunet JM, Djilas SM, Cetkovic GS (2005). Free radical scavenging activity of wormwood (Artemisia absinthium) extracts. J. Sci. Food Agric., 85: 265-272.

Cos P, Ying LY, Calomme M, Hu JH, Cimanga Van Poel KB, Pieters L, Vlietinck AJ, Berghe DV (1998). Structure activity relationships and classification of flavonoids as inhibitors of xanthine oxidase and superoxide scavengers. J. Nat. Prod., 61: 71-76.

Delanty N, Dichter MA (2000). Antioxidant therapy in neurologic diseases. Arch. Neurol., 57: 1265-1270.

Gordon MH (1990). The mechanism of antioxidants action in vitro. In: Hudson, B.J.F (Ed.), Food Antioxidants. London, New York, pp. 1-18.

Halliwell B, Gutteridge JM (1998). Free radicals in biology and Medicine. Oxford University Press, Oxford.

Kim D, Jeong S, Lee CY (2003). Antioxidant capacity of phenolic phytochemicals from various cultivars of plums. Food Chem., 81: 321-326.

Kumar SS, Chaubey RC, Devasagayam TPA, Priyadarsini KI, Chauhan PS (1999). Inhibition of radiation-induced DNA damage in plasmid pBR322 by chlorophyllin and possible mechanism(s) of action. Mutat. Res., 425: 71-79.

Lee YR, Woo KS, Kim KJ, Son JR, Jeong HS (2007). Antioxidant activities of ethanol extracts from germinated specialty rough Rice. Food Sci. Biotechnol., 16: 765-770.

Lee J, Kim J, Jang Y (2002). Antioxidant property of an ethanol extract of the stem of Opuntia ficus-indica var. Saboten. J. Agric. Food Chem., 50: 6490-6496.

Li H, Hao Z, Wang X, Huang L, Li J (2009). Antioxidant activities of extracts and fractions from Lysimachia foenum-graecum Hance. Bioresour. Technol., 100: 970-974.

Lloyd DR, Philips D (1999). Oxidative DNA damage mediated by copper (II), iron (II) and nickel (II) Fenton reactions: evidence for site-specific mechanisms in the formation of double-strand breaks, 8hydroxyldeoxyguanosine and putative intrastrand cross breaks. Mutat. Res., 424: 23-36.
Lollinger J (1981). Free radicals and food additives. Taylor and Francis London, p. 21.

Marimuthu P, Wu CL, Chang HT, Chang ST (2008). Antioxidant activity of ethanolic extract from the bark of Chamaecyparis obtusa var Formosana. J. Sci. Food Agric., 88: 1400-1405.

Meir S, Kanner J, Akiri B, Hadas SP (1995). Determination and involvement of aqueous reducing compounds in oxidative defense systems of various senescing leaves. J. Agric. Food Chem., 43: 1813-1815.

Meyer AS, Isaksen A (1995). Application of enzymes as food antioxidants. Trends Food Sci. Tech., 6: 300-304.

Nishikimi M, Rao NA, Yagi K (1972). The occurrence of superoxide anion in the reaction of reduced phenazine methosulfate and molecular oxygen. Biochem. Biophys. Res. Commun., 46: 849-854.

Nostro A, Germanò MP, D'angelo V, Marino A, Cannatelli MA (2000). Extraction methods and bioautography for evaluation of medicinal plant antimicrobial activity. Lett. Appl. Microbiol., 30: 379-84.

Ozcelik B, Lee JH, Min DB (2003) Effects of light, oxygen, and pH on the absorbance of 2, 2-diphenyl-1-picrylhydrazyl (DPPH). J. Food Sci., 68: 487-490. doi:10.1111/j.1365-2621.2003.tb05699.x.

Oyaizu M (1986). Studies on product of browning reaction prepared from glucose amine. Jpn. J. Nutr., 44: 307-315.

Pietta PG (2000). Flavonoids as antioxidants. J. Nat. Prod., 63: 10351042.

Pietta P, Simonetti P, Mauri P (1998). Antioxidant activity of selected medicinal plants. J. Agr. Food Chem., 46: 4487-4490.

Re R, Pellegrini N, Proteggente A, Pannala A, Yang M, Rice-Evans C (1999). Antioxidant activity applying an improved abts radical cation decolorization assay. Free Radic. Biol. Med., 26: 1231-1237.

Repetto MG, Llesuy SF (2002). Antioxidant properties of natural compounds used in popular medicine for gastric ulcers. Braz. J. Med. Biol. Res., 35: 523-534.

Stupans I, Kirlich A, Tuck KL, Hayball PJ (2002). Comparison of radical scavenging effect, inhibition of microsomal oxygen free radical generation, and serum lipoprotein oxidation of several natural antioxidants. J. Agric. Food Chem., 50: 2464-2469.

Shon MY, Kim TH, Sung NJ (2003). Antioxidants and freeradical scavenging activity of Phellinus baumii (Phellinus of Hymenochaetaceae) extracts. Food Chem., 82: 593-597.

Siddhuraju P, Mohan PS, Becker K (2002). Studies on the antioxidant activity of Indian Laburnum (Cassia fistula L.): a preliminary assessment of crude extracts from stem bark, leaves, flowers and fruit pulp. Food Chem., 79: 61-67.

Suganthy N, Kesika P, Pandian SK, Devi KP (2009). Mangrove plant extracts: radical scavenging activity and the battle against food-borne pathogens. Forsch Komplementmed, 16: 41-48.

Surh YJ, Ferguson LR (2003). Dietary and medicinal antimutagens and anticarcinogens: molecular mechanisms and chemopreventive potential-highlights of a symposium. Mutat. Res., 1-8: 523-524.

Yoshida H, Takagi S (1999). Antioxidative effects of sesamol and tocopherols at various concentrations in oils during microwave heating. J. Sci. Food Agric., 79: 220-226.

Yu L, Haley S, Perrat J, Harris M, Wilson J, Qian M (2002). Free radical scavenging properties of wheat extracts. J. Agric. Food Chem., 50: 1619-1624.

Zahin M, Ahmad I, Aqil F (2010). Antioxidant and antimutagenic activity of Carum copticum fruits extracts. Toxicol. In Vitro, 24: 1243-1249. 